\title{
Some Achievements and Problems of the Protection of Chinese Mask Culture
}

\author{
Bi Xuling* \\ Institute of Literature, Shanghai Academy of Social Sciences, China
}

\begin{abstract}
Chinese mask culture has a long history and a great variety. The protection of Chinese mask culture has made a lot of progress at the beginning of the 21st century. However, the protection of China' mask culture is still facing great challenges. First, the lack of inheritors is the most important issue in the cultural heritage of Chinese masks. Second, Shoddy mask products also influenced the development of mask art. Third, the issue of intellectual property protection of masks meet some difficult. Fourth, the basic activity place of folk mask art is the countryside. Only by protecting the whole mask art can we effectively protect the living mask. We should explore an approach for holistic conservation.
\end{abstract}

Keywords: Mask culture, Achievements and problems, Holistic conservation

\section{(I) An Overview of Chinese Mask Culture}

Chinese mask culture has a long history and a great variety. There are five types are most popular and influential: Nuo Opera mask, Tibetan Opera mask, Shaman mask, folk mask of music and dance, Tun kou mask.

Nuo opera, also known as the Nuo dance. The rudiment of Nuo opera is the folk sacrificial ceremony used to drive off ghosts. Later, the ceremony absorbed the characteristics of folk and produced Nuo drama. The hometown of Nuo opera is Xiangxi area of Hunan Province. During the Kangxi period of the Qing dynasty, the Nuo opera in Xiangxi area developed rapidly. The Nuo opera is popular in Jiangxi Province, Guizhou Province, Anhui Province, Hunan Province, Hubei Province, Guangxi Province, Yunnan Province, Sichuan Province, Shanxi Province, Guangdong Province and Jiangsu Province. Mask is an important tool to show identity for Nuo opera.In different regions of China, Nuo opera has different names, such as Nuotang Opera, Duangong Opera, Shigong Opera, Di Opera, Guansuo Opera, etc. Different Nuo Opera use different masks, which formed a variety of Nuo Opera mask.

Tibetan mask has a long history. According to the frescos of Sangye Temple and Dazhao Temple, Tibetan mask appeared in the 8th century BC. From the 14th century, mask has used in Tibetan Opera. The early Tibetan Opera mask was made of goatskin, with blue mask and white mask. Later, Tibetan mask has made of paper and cloth. According to the contents, Tibetan Opera mask can be divided into king mask, princess mask, fairy mask, demon mask and other role mask. To modern Tibetan Opera, different color mask shows different character of role like the Peking Opera face. For examples, the white Tibetan Opera mask symbolizes pure, kind and warm. The Blue Tibetan Opera mask symbolizes brave and justice. The Black Tibetan Opera mask

\footnotetext{
${ }^{*}$ Bi Xuling, Doctor of folklore, associate research fellow, institute of literature, Shanghai academy of social sciences, China.
} 
symbolizes evil. The Yellow Tibetan mask represents the living Buddha or the fairy. The Green Tibetan mask represents old woman such as queen and mother.

Shamanism was a primitive religion of northern China, which was born in primitive matriarchal clan society. Shaman mask formed in the matriarchal clan society too. Therefore, most of Shaman masks are goddess masks. Shaman masks are used to Shaman dance for gods, a living fossil of shamanism. The shaman, the mediator of god and man, simulates animal or monster when he or she dances for gods. The shaman have to put on a mask, because the shaman fear that he or she be recognized by the dead or gods. In modern China, the Shaman mask of Manchu nationality is the most typical shaman mask.

Folk mask of music and dance is used for folk singing and dancing. There are a little or not any component of faith in the folk singing and dancing. People sing or dance for fun. They put on masks to pretend gods, monsters, famous historical figures, the mythological characters. In modern China, the Folk mask of music and dance mainly exists in the areas inhabited by Minorities such as Yunan province and Guangxi province.

Swallowing Mouth mask is hang on the door head to drive off evil spirits in the areas inhabited by Minorities such as Yunnan province, Guizhou province, Sichuan province and Hunan province. The Swallowing Mouth mask has many forms. The more common type of Swallowing Mouth mask is the beast head, and part of the Swallowing Mouth mask is the combination of man and beast. Some people hang the gourd or ladle for Swallowing Mouth. The Swallowing Mouth mask originated from totem worship and primitive religion, which is the combination of totem culture and witch culture. People believe ferocious beast can swallow up all evil spirits.

The following map shows the distribution of the above four kinds of Chinese masks, including Nuo opera mask, Tibetan Opera mask, Shaman mask and Swallowing mouth mask. The distribution of Folk mask of music and dance is too widely to show. 
Map 1

\section{The distribution of four kinds of Chinese masks}

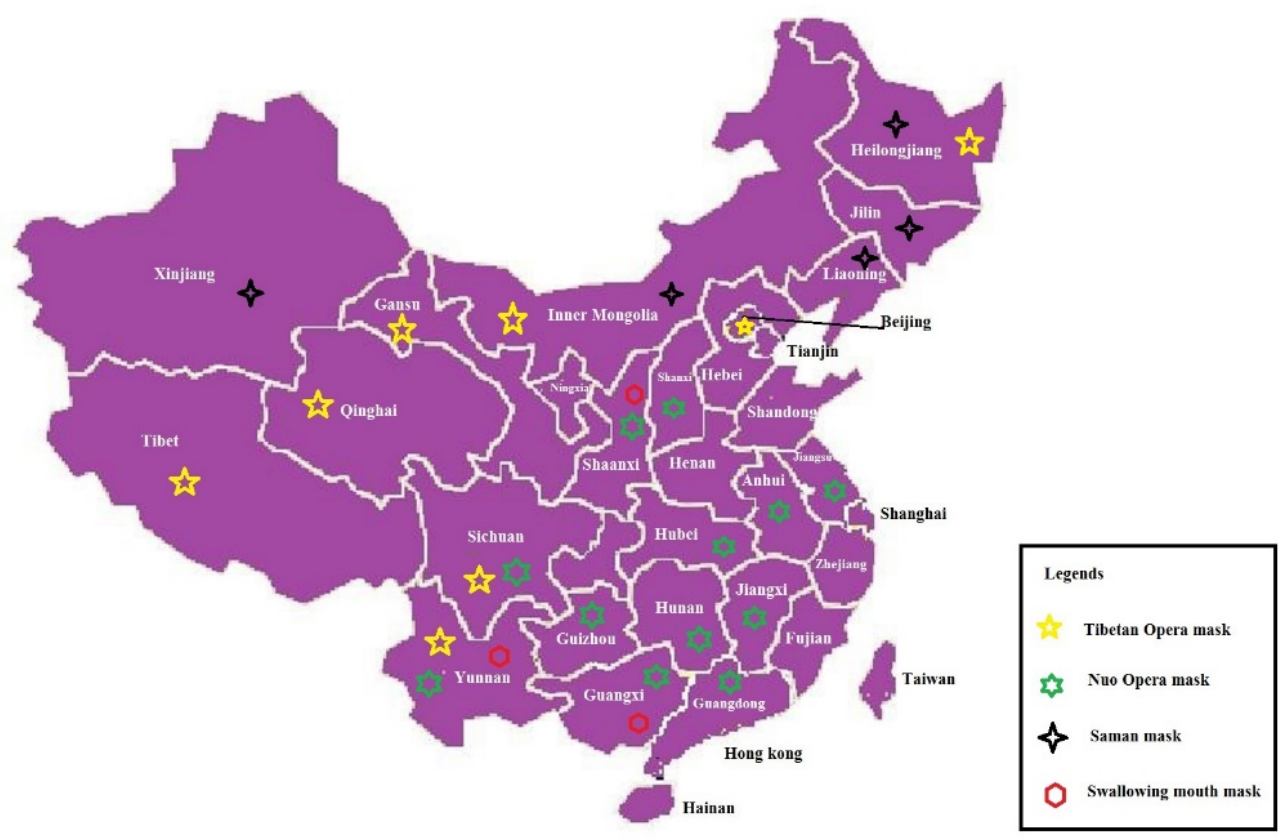

\section{(II) The Protection of Chinese Masks Culture in the Protection of} Intangible Cultural Heritage

As mentioned above, the Chinese mask culture resources are very rich, and the resources are very important intangible culture heritage. Chinese mask culture has had a glorious history, and it has been in a low tide. At the turn of the century, the decline of Chinese mask culture is obvious. At that time, the loss and destruction of masks are serious, especially the number of masks inherited from ancient times dropped sharply. The information about the mask also lacks systematic arrangement and research. The situation has not improved until the beginning of the Chinese intangible cultural heritage protection movement.

Here is an example of Nuotang Opera from Dejiang County of Guizhou province. Nuotang Opera is an important category of Nuo Opera family, many performances of Nuotang Opera in the living room, so named "Nuotang Opera"1. Nuotang Opera covers a wide area, most of Guizhou Province's counties and cities have the trace of Nuotang Opera. Nuotang Opera resource is most abundant in some areas, such as Dejiang County. According to the survey of Dejiang County Government, there were 103 Nuotang Opera troupes, 514 witches or wizards in the 1980s. In 58 villages and towns of Dijiang County, Nuotang Opera performed in 47 villages

${ }^{1}$ Nuotang Opera is written in 傩堂戏 in Chinese. The pronunciation of the “堂”is “Tang”, which means the living room. 
and towns. There were 62 Nuotang Opera troupes, which have almost all Nuotang Opera masks. At that time, the masks of Dejiang County were not only large quantity but also high quality. In the winter of 1987, Beijing Museum of Art held “Guizhou folk Nuo mask exhibition”. The exhibition exhibited 107 ancient Nuotang Opera masks. Since then, Dejiang mask has had famous at home and at abroad. Dejiang County was known as the hometown of "China Opera living fossil”.

The production of Dejing County mask is very characteristic. Nuotang Opera mask is carved by carving mage who is a number of one Nuotang Opera troupe. Willow wood or poplar wood is the main mask material. Willow wood is believed to have the function of driving off evil. The behavior of making mask with willow wood contains a certain religious consciousness. Poplar wood is light and not easy to crack, easy to carve. Compared with other masks, the production process of Nuotang Opera mask is more complicated and more delicate in art. In order to highlight the role of character and enhance performance, folk artists made some masks (such as the God of Land, Mountain King, etc.) movable, with a rope and bamboo sticks to connect several parts of the mask. Such a mask is called "active mask".

The precious mask culture suffered a cold reception in 1990s and gradually declined. The situation lasted until the beginning of 21st century. The Guizhou Metropolis Daily reported on February 26, 2003 that Nuotang Opera of Dejiang County has almost disappeared. Six scholars from Beijing did not see the performance of Nuotang Opera in their investigation. A few years later, with the Chinese intangible cultural heritage protection movement, the Nuotang Opera of Dejiang County was back to life. In 2006, Nuotang Opera of Dejiang County was inculded in the first batch of national intangible cultural heritage protection list. In 2008, the Minstry of Culture awarded Dejiang County the title of "Chinese folk culture and folk art village" and "Nuo Opera village" .

Chinese intangible cultural heritage protection movement is an opportunity for the revival of Chinese mask culture. Many cultural items related to masks have entered the system of intangible cultural heritage at all level$^{2}$. The benefits of being an intangible cultural heritage project are obvious, with economic and cultural influences increasing. It should be noted that the mask described in this article is a living mask, not a museum exhibit. In another words, mask is a part of the synthetic art. As a result, there are very few mask projects in the list of intangible culture heritages at all levels, while there are many projects related to mask in the list of intangible cultural heritage. For example, there are only one project of mask among 1,354 Chinese national intangible culture heritage projects. It is the Xiangdong Nuo Opera Mask from Pingxiang city, Jiangxi province. However, we can give many examples about national intangible cultural heritage projects related to mask. They are "Cuo tai ji" Opera, Nuo Opera (narrow sense), Anshun Di Opera, Guansuo Opera, Sichuan Opera, Yang Opera etc. Mask is a necessary and important part among those operas. Therefore, the above opera projects are all projects related to mask.

The situation is similar in provincial intangible cultural heritage projects. Let us take Guizhou Province as an example too. There are 476 provincial intangible cultural heritage projects in Guizhou Province, but there are only one projects of mask among them. It is the production of Nuo mask from Dejiang County. Actually, mask cultural resource is very rich in Guizhou Province. Mask cultural resources are distributed in most counties and states of Guizhou Province.The following map shows main mask cultural resources in Guizhou province.

\footnotetext{
2 The system of China's intangible cultural heritage protection is divided into four levels: national, provincial, city level and county level.
} 


\section{Map 2}

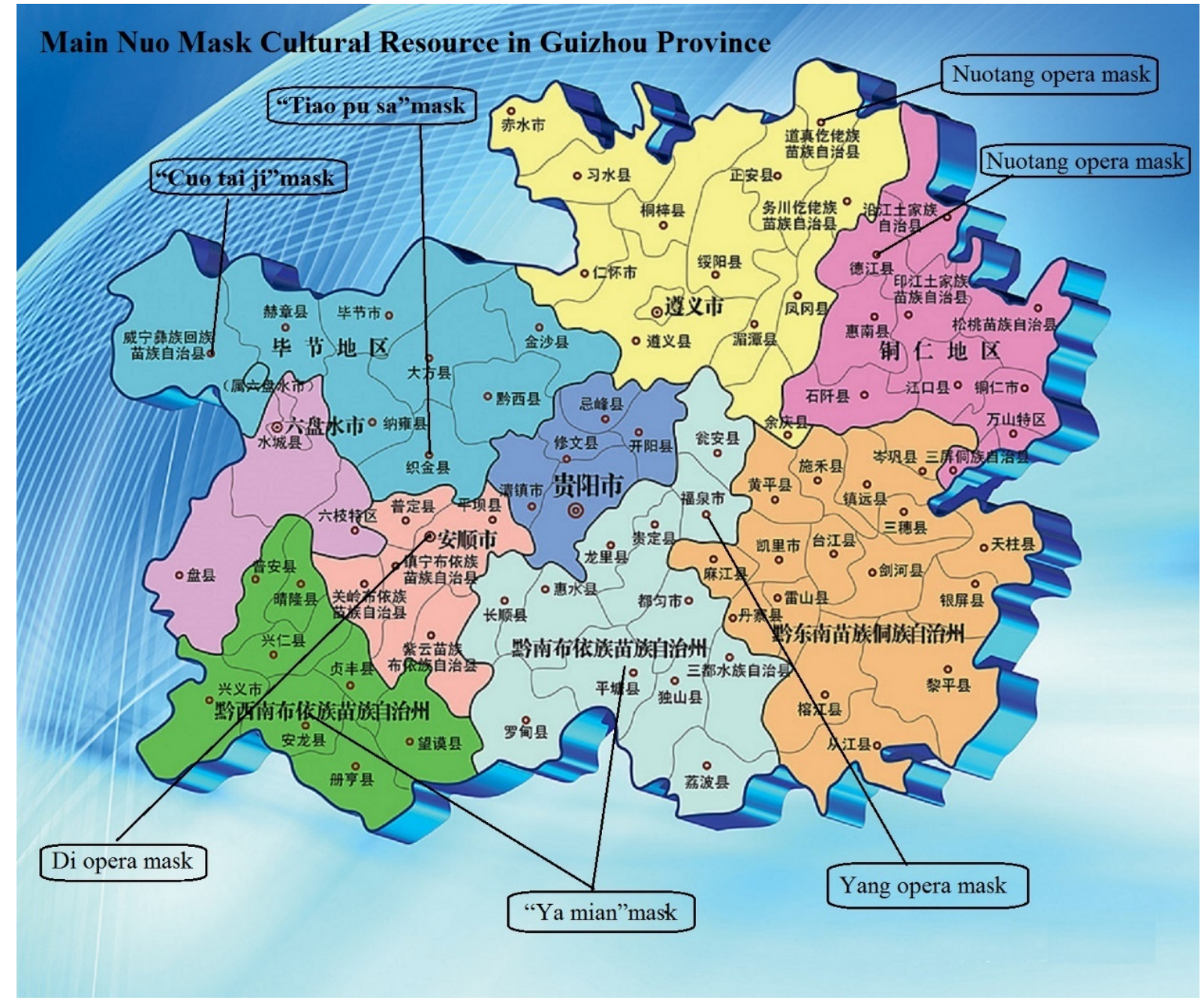

Those mask of Guizhou province at the above map belong to one mask type-the Nuo Opera mask. It is obvious that Nuo mask resources of Guizhou province are abundant. The most important reason may be there are many ethnic groups inhabit here. Under the influence of Nuo culture, different ethnic groups created different Nuo Opera and Nuo Opera masks. Relatively famous Nuo Opera masks are Di Opera mask and Yang Opera mask of the Han nationality, "Cuo tai ji" mask of the Yi nationality, "Ya mian" mask of the Buyi nationality, "Tiao pu sa" mask of the Chuanqing nationality. Those Nuo Opera masks have their own distinct characteristics. For examples, the Di Opera mask from Anshun city is famous for its fine carving. The features of the "Cuo tai ji" mask from Bijie City is rustic.

The above wonderful masks have become intangible cultural heritage project in various forms. In addition, they have been well protected. For example, the woodcarving from Anshun city is provincial intangible cultural heritage project of Guizhou Province, and its main content is carving of Anshun Di Opera mask. "Cuo tai ji" from Bijie City is not only a provincial intangible cultural heritage project of Guizhou Province, but also a national intangible cultural heritage project. The Yang Opera from Fuquan City and Nuotang Opera of the Gelao nationality have also been included in the provincial intangible cultural heritage list of Guizhou Province. 
The following table shows the situation that the main mask cultural resources were selected at all levels of intangible cultural heritage.

Table 1

\begin{tabular}{|c|c|c|c|}
\hline District & $\begin{array}{l}\text { Name of mask cultural } \\
\text { resource }\end{array}$ & Nation & $\begin{array}{l}\text { The status of intangible cultural } \\
\text { heritage at all levels }\end{array}$ \\
\hline $\begin{array}{l}\text { Anshun City } \\
\text { (安顺市) }\end{array}$ & $\begin{array}{l}\text { Di opera mask } \\
\text { (地戏面具) }\end{array}$ & $\begin{array}{l}\text { The Han nationality } \\
\text { ( 汉族 ) }\end{array}$ & $\begin{array}{l}\text { Anshun Di Opera: national intangible } \\
\text { cultural heritage } \\
\text { (安顺地戏：国家级非物质文化遗产) }\end{array}$ \\
\hline $\begin{array}{l}\text { Weining County, Bijie City } \\
\text { (毕节市威宁县) }\end{array}$ & $\begin{array}{l}\text { “Cuo tai ji”mask } \\
\text { (“撮泰吉”面具) }\end{array}$ & $\begin{array}{l}\text { The Yi nationality } \\
\text { ( 彝族 ) }\end{array}$ & $\begin{array}{l}\text { Cuo tai ji of Yi nationality: national } \\
\text { intangible cultural heritage } \\
(\text { 彝族撮泰吉：国家级非物质文化遗产) }\end{array}$ \\
\hline $\begin{array}{l}\text { Qianxinan State and Qiannan State } \\
\text { (黔西南州和黔南州) }\end{array}$ & $\begin{array}{l}\text { “Ya mian”mask } \\
\text { (“哑面”面具) }\end{array}$ & $\begin{array}{l}\text { The Buyi nationality } \\
\text { (布依族 ) }\end{array}$ & $\begin{array}{l}\text { Libo Nuo Opera of Buyi nationality: } \\
\text { national intangible cultural heritage } \\
(\text { (荔波布依族傩戏：国家级非物质文化遗 } \\
\text { 产) }\end{array}$ \\
\hline $\begin{array}{l}\text { Daozhen County，Zunyi City } \\
\text { (遵义市道真县) }\end{array}$ & $\begin{array}{l}\text { Nuotang opera mask } \\
\text { (傩堂戏面具) }\end{array}$ & $\begin{array}{l}\text { The Gelao nationality } \\
\text { ( 仡佬族 ) }\end{array}$ & $\begin{array}{l}\text { Daozhen Nuo Opera: national intangible } \\
\text { cultural heritage } \\
\text { (道真傩戏：国家级非物质文化遗产) }\end{array}$ \\
\hline $\begin{array}{l}\text { Dejiang County, Tongren City } \\
\text { (铜仁市德江县) }\end{array}$ & $\begin{array}{l}\text { Nuotang opera mask } \\
\text { (傩堂戏面具) }\end{array}$ & $\begin{array}{l}\text { The Tujia nationality } \\
\text { (土家族) }\end{array}$ & $\begin{array}{l}\text { Dejiang Nuotang Opera: national } \\
\text { intangible cultural heritage } \\
\text { (德江傩堂戏：国家级非物质文化遗产) }\end{array}$ \\
\hline $\begin{array}{l}\text { Zhijin County, Bijie City } \\
\text { (毕节市织金县) }\end{array}$ & $\begin{array}{l}\text { “Tiao pusa”mask } \\
\text { (“跳菩萨”面具) }\end{array}$ & $\begin{array}{l}\text { The Chuanqing } \\
\text { nationality } \\
\text { ( 穿青族 ) }\end{array}$ & $\begin{array}{l}\text { Zhijin Nuo Opera of Chuanqing } \\
\text { nationality: provincial intangible cultural } \\
\text { heritage } \\
\text { (织金穿青人傩戏：贵州省非物质文化遗 } \\
\text { 产) }\end{array}$ \\
\hline $\begin{array}{l}\text { Longchang Town, Fuquan City } \\
\text { (福泉市龙昌镇) }\end{array}$ & $\begin{array}{l}\text { Yang opera mask } \\
\text { (阳戏面具) }\end{array}$ & $\begin{array}{l}\text { The Han nationality } \\
\text { ( 汉族 ) }\end{array}$ & $\begin{array}{l}\text { Fuquan Yang Opera: provincial intangible } \\
\text { cultural heritage } \\
\text { (福泉阳戏:贵州省非物质文化遗产) }\end{array}$ \\
\hline
\end{tabular}

\section{(III) Challenges Faced by Chinese Mask Culture Protection}

From the above, it is clear that the protection of Chinese mask culture has made a lot of progress at the beginning of the 21st century. However, the protection of China' mask culture is still facing great challenges.

First, the lack of inheritors is the most important issue in the cultural heritage of Chinese masks. As the time goes by, the old artists died one after another. For various reasons, Yong people are reluctant to learn the art of mask. Some young people do not understand the value of mask art. They think that ancient masks are outdated and ugly. Others abandon the idea of working in mask art for economic reasons. A great deal of valuable mask material is lost because there is no suitable inheritor.

There is an example of "Cuo tai ji". "Cuo tai ji" is Yi language, an old opera. "Cuo" means person or ghost. "Tai” means change. "ji” means play or game. "Cuo tai ji” means "the age of human being’s birth” or "the game of human change". Some scholars believe that "Cuo tai ji" reflects the difficult situation of migration, reclamation of Yi Nationality's ancestors. It also expressed the hope that ancestors will bless the offspring and expel evil. "Cuo tai ji" masks are very rustic and very special. The masks distinguish the sex and age of a character by wearing beards and drawing lines of different shapes with chalk. 
"Cuo tai ji” had been widely spread in the area where Yi people live. Now it only spread in Luojia Village, Bandi Township, Weining County, Bijie City, Guizhou Province. There are only a few dozen households and hundreds of people in the village. "Cuo tai ji" is inherited in one "Bimo" family. "Bimo" is the host and the main participant of "Cuo tai ji". Wen Daohua is representative inheritors. Wen Daohua's father passed on his knowledge of "Cuo tai ji" to him. However, when Wen Daohua was old, his two sons were reluctant to carry on the family heritage because of the influence of religion and modern culture. Family inheritance is its main mode of inheritance. So the range of inheritance is too narrow. Finally, Wen Daohua had to pass on the family heritage to his nephew.

Second, Shoddy mask products also influenced the development of mask art. The 1980s is the golden age for the development of Chinese masks. The mask was independent from opera, and its production in large quantities as commodities. However, the mask production skills are in the hands of folk artists. Their families became small workshops for the production of mask goods. In order to make more and more money, many workshops accelerated the process of production, reduced production process, and produced a large number of rough mask products. The workshop also used cheap wood, which produced masks were easily cracked. With the development of tourism, the situation is more serious. Just as bad money drives out good money in Economics. The cheap and inferior masks occupied most of the mask market, and the quality masks lost their living space.

The Di Opera mask industry in Anshun City is an example. Anshun Di Opera is one kind of Nuo Opera. It is a special Jun Nuo related to ancient army. Di Opera is one of main group activities for Tunbao people who are the offspring of the Ming Dynasty soldiers. It is a multi-functional opera form of praying for God, entertaining God, self-entertainment and fitness. In order to meet the needs of Di Opera for masks, Anshun has created some special sculpture artist. Di Opera mask is produced by lilac wood or poplar wood. It is characterized by fine workmanship and vivid image. The Di Opera mask is composed of three parts: face, cap and ears. In the large category, the Di Opera mask is divided into five categories: scholars, knights, the elderly, children, and women. The five categories commonly are known as "five colors faces". Of course, there are small categories in each category.

In 1980s, Anshun Di Opera was well known both at home and abroad. Many actors often performed in France or Spain. The situation attracted so many people go to Anshun to buy Di Opera masks. Some farmers also learned to make masks. However, they lacked understanding and respect for the mask art, and only seek economic benefits, so the mask production were very rough and lacking of creativity. Gradually, many dealers were not reluctant to buy those masks. The wholesale price of an Anshun Di Opera mask was more than 30 RMB at the end of 20th century. 10 years later, one piece only sells a dozen pieces of RMB. The situation of the Di Opera masks being neglected also affected the development of the Di Opera. The audience groups are gradually shrinking. In Anshun, some professional mask artists had to leave hometown to make a living elsewhere. There are fewer and fewer local mask artists in Anshun.

Third, the issue of intellectual property protection of masks meet some difficult. The mask is a special creation. The mask is a sculpture artist, according to the content of folk opera or ritual, plus the creation of personal conception and creation; it is a tangible carrier with originality and replicability. Therefore, copyright law should protect mask works. In fact, it is difficult to protect mask works by the intellectual property rights law. The main reasons are as follows: (1) intellectual property rights of masks are liable to be violated. Because most of the masks are made of easy to obtain material, the method of production is easy to learn. Therefore, 
masks are easy to imitate. (2) The mask is perfected in the succession of generations, and is the result of free circulation and accumulation. The copyright protection will restrict the development of freedom, and may affect the development of the mask. (3) Many mask works are actually collective creation. Some ancient masks do not have intellectual property rights holders, so they cannot fully protect the intellectual property rights of such art forms as masks.

Fourth, the basic activity place of folk mask art is the countryside. However, with the development of urbanization in China, the area of rural areas has become smaller and smaller. Great changes have taken place in the villagers' ideas and production and life. Large numbers of adults leave their native lands and work in cities. The audience of mask art is shrinking dramatically.

\section{(IV) Exploring a New Model of Mask Culture Protection}

As mentioned earlier, mask art is a comprehensive art. The living mask is one part of the synthetic art. Therefore, only by protecting the whole mask art can we effectively protect the living mask. We should explore an approach for holistic conservation.

First, we should protect the mask itself. However, the protection of mask culture should be extended to other aspects related to mask. The method of overall protection should include the carrier of masks, such as various folk operas and ceremonies. It should also include mask-making artists and mask art inheritors. In addition, the living space of mask art should be protected. The four are linked together to form an indivisible whole. Among them, mask protection is center, the protection of mask carrier is the foundation, the protection of artists and inheritors are the focus, the protection of cultural space is supporting. Thus, the protection pattern of human being, material, carrier and space as a whole will be formed, as shown in the following figure.

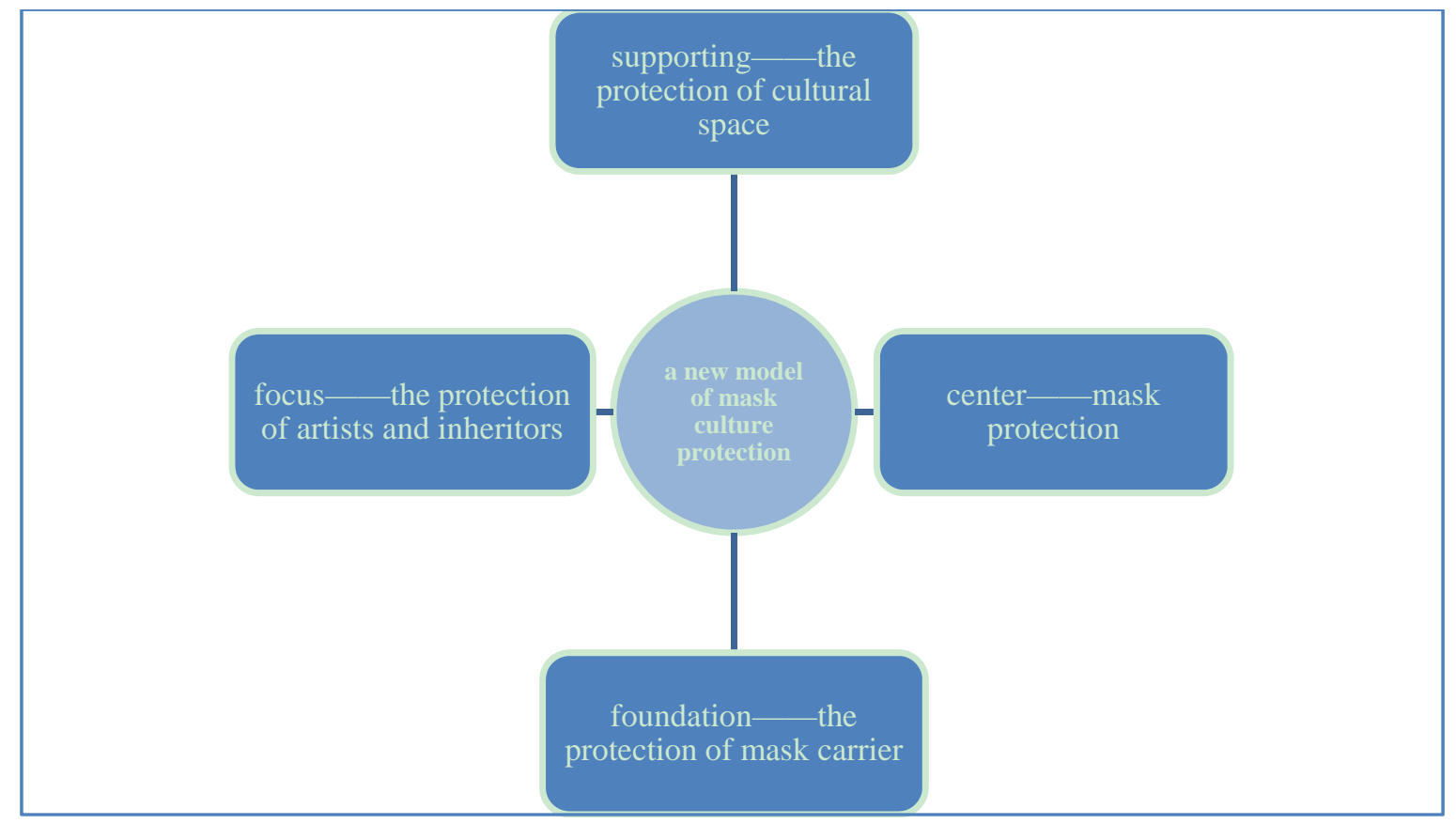

Figure 1. 